\title{
Primer immunhiány és autoimmun betegségek
}

\author{
Múzes Györgyi dr. - Sipos Ferenc dr. \\ Semmelweis Egyetem, Általános Orvostudományi Kar, II. Belgyógyászati Klinika, Budapest
}

\begin{abstract}
A primer immunhiányos betegségek a természetes és az adaptív immunrendszer elemeit érintő, genetikailag heterogén immunológiai rendellenességek. A primer immunhiányban szenvedő betegek nemcsak visszatérő fertőzésekre, de noninfektív kórállapotokra, így gyulladásos vagy granulomatosus eltérésekre, lymphoproliferativ és szolid daganatos megbetegedésekre, autoinflammatiós állapotokra, valamint a legkülönfélébb autoimmun kórformákra is hajlamosabbak. Az elsődleges immunhiány és az autoimmunitás paradoxonnak tűnő együttes megjelenése valódi kihívást jelent az immunhiányos betegek autoimmun szövődményeinek felismerésében. A primer immunhiányos állapotok hátterében általában egy vagy több, az immunregulációban és/vagy az immuntolerancia kialakításában kulcsszerepet játszó gén mutációja áll. A szerteágazó immunológiai rendellenességek, a kompenzatorikus, túlzott mértékú krónikus gyulladásos válaszreakció és a következményes szövetkárosodás együttese végső soron szerv-, sejtspecifikus vagy szisztémás autoimmun betegségek kialakulásához vezet. Számos primer immunhiányos kórképet különböző, sajátos autoimmun manifesztáció jellemez. A jelen összefoglaló célja a primer immunhiányos állapotokban megjelenő autoimmun kórképek, valamint az immunrendszeri rendellenességek alapjául szolgáló molekuláris és celluláris mechanizmusok áttekintése. A dolgozat végén ismertetett eset rávilágít arra, hogy immunhiányos állapotokban az autoimmun betegségek felismerése, illetve a dominálóan autoimmun kórkép formájában induló fenotípusoknál az immunhiány kórismézése egyaránt kihívást jelenthet.
\end{abstract}

Orv Hetil. 2018; 159(23): 908-918.

Kulcsszavak: primer immunhiány, autoimmunitás, autoimmun betegségek

\section{Primary immunodeficiency and autoimmune diseases}

Primary immunodeficiencies consist of a group of genetically heterogeneous immune disorders affecting distinct elements of the innate and adaptive immune system. Patients with primary immunodeficiency are more prone to develop not only recurrent infections, but non-infectious complications, like inflammatory or granulomatous conditions, lymphoproliferative and solid malignancies, autoinflammatory disorders, and a broad spectrum of autoimmune diseases. The concomitant appearance of primary immunodeficiency and autoimmunity appears to be rather paradoxical, therefore making the diagnosis of immunodeficiency patients with autoimmune complications challenging. Mutations of one or more genes playing a fundamental role in immunoregulation and/or immune tolerance network are thought to be responsible for primary immunodeficiencies. The diverse immunological abnomalities along with the compensatory and excessive sustained inflammatory response result in tissue damage and finally in manifestation of organ-, cell-specific or systemic autoimmune diseases. Several forms of primary immunodeficiency disorders are characterized by a variety of specific autoimmune phenomena. This overview addresses the spectrum of autoimmune diseases associated with primary immunodeficiencies, and explores the molecular and cellular mechanisms underlying abnormalities of the immune system. The case presented finally highlights that both the recognition of autoimmune diseases in association with immunodeficiencies and the diagnosis of immunodefiency in those phenotypes with predominant autoimmunity could be challenging.

Keywords: primary immunodeficiency, autoimmunity, autoimmune diseases

Múzes Gy, Sipos F. [Primary immunodeficiency and autoimmune diseases]. Orv Hetil. 2018; 159(23): 908-918.

(Beérkezett: 2018. január 23.; elfogadva: 2018. február 13.) 


\section{Rövidítések}

$\mathrm{ACPA}=$ anticitrullinált protein elleni antitestek; $\mathrm{AD}=$ autoszomális domináns; $\mathrm{ADA}=$ adenozin-dezamináz; $\mathrm{AH}=$ autoimmun hepatitis; AICDA = aktiváció indukálta citidin-dezamináz; AID = autoinflammatiós kórkép; AIHA = autoimmun haemolyticus anaemia; AIRE = autoimmun regulátor; ALPS = autoimmun lymphoproliferativ szindróma; $\mathrm{AP}=$ anaemia perniciosa; $\mathrm{AP} 3 \mathrm{Bl}=($ adaptor related protein complex-3-beta- 1$)$ adapterrel kapcsolatos fehérjekomplex-3-béta-1; APECED = autoimmun polyendocrinopathia, candidiasis, ectodermalis dystrophia; APRIL = (proliferation-inducing ligand [TNFSF13] proliferatioindukáló ligand; APS = antifoszfolipidszindróma; $\mathrm{AR}=$ autoszomális recesszív $;$ Artemis $=$ DNS-keresztkötést javító fehérje-1C; ATD = autoimmun thyreoiditis; $\mathrm{BAFF}=\mathrm{B}$ sejt-aktiváló faktor; BAFFR = B-sejt-aktiváló-faktor-receptor; BLNK $=($ B-cell linker $)$ B-sejt-kapcsoló; BTK $=$ Bruton-féle tirozin-kináz; CARD = kaszpáztoborzó doméncsalád; CASP = kaszpáz; $\mathrm{CD}=$ (complement deficiency) komplementhiány; CD40L $=$ CD40-ligand CDP $=($ congenital defects of phagocyte) a phagocytosis veleszületett zavarai; $\mathrm{CeD}=$ coeliakia; Cernunnos $=$ nemhomológvég-csatlakozó faktor-1; CGD = krónikus granulomatosus betegség; CID $=($ combined immunodeficiency) kombinált immunhiányos állapot; CIDP = krónikus gyulladásos demyelinisatiós polyneuropathia; $\mathrm{CMC}=$ idült mucocutan candidiasis; CTLA4 = citotoxikus T-lymphocytaasszociált fehérje- 4 ; CVID $=($ common variable immunodeficiency) variábilis immunhiány; $\mathrm{CYBB}=$ citokróm-b245-bétalánc; $\mathrm{DCM}=$ dilatatív cardiomyopathia; $\mathrm{DID}=($ diseases of immune dysregulation) immundiszregulációs betegségek; DII $=($ defects of innate immunity $)$ a veleszületett immunitás zavarai; DLE = discoid lupus erythematosus; EBV = Epstein-Barrvírus; $\mathrm{EF}=$ ejekciós frakció; $\mathrm{ESID}=($ European Society for Immunodeficiencies) Európai Immunhiány Társaság; FADD = Fas-asszociált-halál-domén; Fas $=\mathrm{CD} 95 ; \mathrm{Fc} \gamma \mathrm{R}=\mathrm{Fc}$-gammareceptor; FHL = familiaris haemophagocytosissal járó szindróma; FOXP3 = forkhead box protein-3; GN = glomerulonephritis; $\mathrm{GOF}=$ (gain-of-function) funkciónyerő; $\mathrm{HAE}=$ hereditaer angiooedema; HSP = Henoch-Schönlein-purpura; IC = immunkomplex; ICOS = (inducible costimulator $)$ indukálható kostimulátor; IDO = indolamin-2,3-dioxigenáz; Ig = immunglobulin; ILD = interstitialis tüdőbetegség; IL17R = interleukin-17-receptor; IL2R = interleukin-2-receptor; IPEX = X-hez kötött immundiszreguláció, polyendocrinopathia, enteropathia; ITCH = Itchy E3-ubikvitin-fehérje-ligáz; ITK = interleukin-2-indukálta T-sejt-kináz; ITP = immunthrombocytopenia; JIA = juvenilis idiopathiás arthritis; LIG4 = DNS-ligáz-IV; LOF = (loss-of-function $)$ funkcióvesztő; LRBA = LPSreszponzív beige-szerű horgonyzó; LYST = lysosomalis közlekedési szabályozó; $\mathrm{MG}=$ myasthenia gravis; $\mathrm{MLPH}=$ melanofilin; MYO5A = myosin-VA; NK-sejt $=$ (natural killer cell) természetes ölősejt; nTreg = természetes szabályozó T-sejtek; NYHA $=($ New York Heart Association $)$ Szívbetegséggel Foglalkozó New York-i Társaság; ORAIl = (calcium release-activated calcium modulator-1) kalciumfelszabadulás által aktivált kalciummodulátor- $1 ; \mathrm{PAD}=$ (predominantly antibody deficiency) elsődleges antitesthiányos állapot; PAN = polyarteritis nodosa; $\mathrm{PBC}=$ primer biliaris cirrhosis; $\mathrm{PI} 3=$ foszfoinozitol-3; PID $=$ (primary immunodeficiency disease $)$ primer immunhiányos betegség; PKC $\delta$ = fehérjekináz-C- $\delta$; PLCG2 = foszfolipáz-C-gamma-2; PNP = purin-nukleozid-foszforiláz; POLE2 $=$ DNS-polimeráz epszilon- 2 alegysége $;$ PPID $=($ phenocopies of PID) PID-szerü állapotok; PRFl = perforin-1;
PSC = primer szklerotizáló cholangitis; PTEN = foszfatáz- és tenzinhomológ; PTPN22 = fehérjetirozin-foszfatáz, nemreceptor 22 -es típus; $\mathrm{PV}=$ pemphigus vulgaris; $\mathrm{RA}=$ rheumatoid arthritis; RAB27A = a RAS onkogén család tagja; RAG = rekombinációaktiváló gén; RMRP = a mitokondriális RNS processing endoribonukleáz RNS-alkotója; SAP = jelátviteliadapter-protein; SCID $=$ (severe combined immunodeficiency) súlyos kombinált immunhiány; $\mathrm{SH} 2 \mathrm{DlA}=\mathrm{SH} 2$-domén-tartalmazó-1A; SHPl = Src-homológ-régió-2 domént tartalmazó foszfatáz-1; SIAE = sziálsav-acetilészteráz; $\operatorname{sIgAD}=$ szelektív IgA-hiány; SLE = szisztémás lupus erythematosus; SS = Sjögren-szindróma; STAT $=$ (signal transducer and activator of transcription) jelátvivő és transzkripcióaktivátor; STIMI = stromalis interakciós molekula- 1 ; STXIl = szintaxin- 11 ; STX$\mathrm{BP} 2$ = szintaxinkötő fehérje- $2 ; \mathrm{T} 1 \mathrm{DM}=1$-es típusú diabetes mellitus; TACI $=$ (transmembrane activator and calcium-modulating cyclophilin ligand interactor [TNFRSF13B)] transzmembránaktiváló és kalciummodulátor ciklofilinligand-közremúködő; TGF = transzformáló növekedési faktor; TNFRSF = tumornekrózisfaktor-szupercsalád; TSA = (tissue specific antigen) szövetspecifikus antigén; tTG = szöveti transzglutamináz; UNC13D = Unc-13-homológ-D; UNG = uracil-DNSglikoziláz; XIAP = X-hez kötött apoptózisgátló fehérje; XL = (X-linked) X-kromoszómához kötött öröklődés; XLA = X-hez kötött agammaglobulinaemia, Bruton-féle agammaglobulinaemia; XLP = X-kromoszómához kapcsolódó lymphoproliferatio; ZAP70 = T-sejt-receptor-asszociált proteinkináz-70-zétalánc

Napjainkban a veleszületett/primer immunhiányos betegségek (PID-ek) heterogén csoportjába - a molekuláris biológiai és elméleti immunológiai ismeretek/módszerek robbanásszerű fejlődésének köszönhetően - már 354, az immunfunkciók genetikailag meghatározott zavarán alapuló rendellenesség sorolható [1]. A természetes és a szerzett védelmi rendszer immunkompetens sejtjeinek inherens károsodása - és a következményes funkcionális rendellenességek - a sejtek fejlődésbiológiai (differenciálódási/érési) zavarára vezethetők vissza. Bár általában ritka betegségcsoportnak tekintik, a felismert esetek száma folyamatosan növekszik [2]. Összesített gyakoriságukat 100000 élveszülésre vetítve aktuálisan 4-10 körülinek becsülik [3]. Egyes kórképek akár már a születést követően, illetve csecsemő- és kisdedkorban drámaian megnyilvánulnak, máskor felnőttekben, olykor tünetek hiányában, véletlenszerúen kerülnek felismerésre. A rendkívül változatos klinikai fenotípusok közös, jellemző tünete az infekciók iránti feltűnő fogékonyság, ám emellett gyakran kísérik autoimmun, autoinflammatiós és malignus kórformák. A legtöbb PID monogénes természetű, és a kóros gén öröklődése a klasszikus Mendel-szabályokat követi, míg a poligénes (multifaktoriális hátterü) típusok klinikailag jóval heterogénebbek.

Az immunhiány és az autoimmunitás együttes fennállása - a hagyományos orvosi gondolkodás szerint - paradoxonnak tû́nhet, hiszen a kórállapotok látszólag ellentétes szabályozási hátteret feltételeznek. Mégis az autoimmun jelenségeknek, a legkülönfélébb - szerv-, 
sejtspecifikus, illetve szisztémás - autoimmun betegségeknek PID-ben megfigyelt gyakori előfordulása az immunreguláció inherens, komplex, átfedő zavarát támasztja alá $[4,5]$.

PID-ben - az átlagnépességet érintő autoimmun kórképektől eltérően - nem érvényesül nemi vagy életkorfüggőség, sem a lehetséges manifesztációk szöveti vagy szervi szintú restrikciója; adott autoimmun betegség a PID zajlása során bármikor felléphet $[3,5]$. Nem egyértelmú, hogy egyes autoimmun kórképek miért csak bizonyos PID-formákkal asszociálódnak. A leggyakoribb autoimmun megnyilvánulások a cytopeniák, az endocrin szervek érintettsége és az enteropathiák [6]. A PID-betegek között elsősorban a T-sejteket érintő típusok esetén kifejezett egy adott autoimmun kórkép kialakulási rizikója. $\mathrm{Ha}$ az autoimmun kórállapot szokatlanul fiatal életkorban („early-onset”) manifesztálódik, egyidejü PID fennállására hívhatja fel a figyelmet. Másrészt a több szervet érintő, de eltéró életévekben megjelenő autoimmun természetű megbetegedések (poliautoimmunitás) szintén PID-re utalhatnak. Az életkilátások tekintetében a PID-hez társuló autoimmun kórkép egyértelmúen előnytelen prognosztikai faktort képvisel [3].

A következőkben - a nagyszámú ismert PID miatt a teljesség igénye nélkül - összefoglaljuk a legismertebb veleszületett immunhiányos állapotokban előforduló szervspecifikus és szisztémás autoimmun betegségeket.

\section{A primer immunhiányos megbetegedések (PID) osztályozása}

A PID-ek fóbb csoportjait az alábbi kórállapotok jelentik: 1) kombinált immunhiány (CID), 2) CID, szindrómás jelleggel, 3) elsődleges antitesthiány (PAD), 4) immunregulációs zavarral jellemzett formák (DID), 5) a phagocytosis veleszületett zavarai (CDP), 6) a veleszületett immunitás zavarai (DII), 7) autoinflammatiós kórképek (AID), 8) komplementhiány (CD) és 9) PID-szerú állapotok ( PPID) $[7,8]$.

$\mathrm{Az}$ elsödleges antitesthiányos állapotok (PAD) különösen gyakoriak (50-60\%), a B-sejtek jellemző zavarával. A spektrum igen széles: az összes Ig-osztály kritikusan alacsony szintjétől és a B-sejtek teljes hiányától a szelektív Ig-hiányon át a normális szérum-Ig-szintekig terjed. A fellelhető génhibák fóleg a BTK-t érintik ( 85\%), korai B-sejt-defektusra vezetve. Szintén gyakori a CD40L $(\sim 70 \%)$ és a TNFRSF13B ( 10\%) gének mutációja: az Ig-osztály-váltás defektusát és a terminális B-sejtek zavarát okozzák. Világviszonylatban a PAD-formák közül az sIgAD, majd a CVID a leggyakoribb. Fő jellemzőjük a hypogammaglobulinaemia; a klinikum idült, visszatérő fertőzések mellett krónikus gyulladásos állapotok és autoimmun jelenségek/betegségek formájában nyilvánul $\operatorname{meg}[9,10]$.

A kombinált immunbiányos állapotok (CID), szindrómás jelleggel vagy a nélkül) a PID-ek 5-15\%-át képviselik. Intracelluláris bakteriális és virális infekciók mellett az autoimmunitás is gyakori jelenség, fóleg a T-sejtek domináló múködési rendellenessége esetén. A RAG, az IL2RG, az IL17RA, a LIG4, az ADA, a PNP stb. gének mutációi kevéssé változatos receptorkészletû autoreaktív T-sejtek megjelenését idézik elő, kedvezve számos autoimmun kórforma megjelenésének [5].

$\mathrm{Az}$ immunregulációs zavarral jellemzett kórképek (DID, 3\%) egy részében meghatározó elem valamely autoimmun betegség kialakulása. Legismertebb klinikai manifesztációi az APECED, az IPEX és az ALPS [11].

A congenitalis phagocytadefektusok (CDP, 5\%), a komplementhiány állapotai (CD, 6\%) és a természetes immunitás defektusai (DII, 1\%) többnyire gyermekkorban manifesztálódnak, visszatérő fertőző betegségeket okoznak. Ugyanakkor ezen immunhiányos állapotokban is számolni lehet idült gyulladásos állapotok és autoimmun betegségek megjelenésével [12].

\section{Az autoimmunitás kialakulásának főbb mechanizmusai primer immunhiányban (PID)}

A PID-ben megjelenő autoimmun állapotok kialakulásának mechanizmusa összetett; így megemlíthetók 1) a centrális és a perifériás tolerancia adaptív immunitást érintő defektusai (a T-sejt-tolerancia-indukció zavarai; az autoreaktív T-sejtek apoptózisának, aktiváció indukálta sejthalálának hibái; a szabályozó Treg-sejtek kialakulásának és funkciójának rendellenességei; az autoreaktív Bsejtek eliminációjának zavara), 2) az immunkompetens sejtek egyes csoportjait érintő genetikai mutációk (például AIRE, FOXP3), 3) a perzisztáló, idült infekciók és gyulladásos állapotok, illetve 4) az apoptotikus sejtek okozta fokozott terhelés és az immunkomplexek csökkent clearance-e $[13,14]$.

Általánosságban elmondható, hogy PID-ben a rekurráló/perzisztáló fertőzések okozta antigénterhelés (molekuláris mimikri és/vagy szuperantigének révén), valamint az antigénclearance zavara egyaránt érintik az immuntolerancia és az ignorancia komplex folyamatait. Ennek következtében az érintett egyénben diszregulált immunválasz és autoimmunitás együttes megjelenésével kell számolni. A gyakori, visszatérő fertőzések a kórokozók eliminációjához nélkülözhetetlen antigénspecifikus lymphocyták proliferatióját idézik elő. Az elkövetkezőkben az aktivált lymphocyták apoptózisa az immunhomeosztázis helyreállításának kulcstényezője. Az apoptotikus sejtekből felszabaduló kromoszomális DNS autoantigénforrás lehet, így kiemelt fontosságú a sejttörmelék (debris) gyulladásos szövetekből történő mielőbbi eltávolítása [15]. PID-betegekben a pusztuló és apoptotikus sejtek phagocytosisa elégtelen. Végeredményben tehát a hibás antigénclearance immunkomplex-lerakódást, sejtaktivációt, idült gyulladást és az érintett szervekben következményes szövetkárosodást okoz. Szövetspecifikus autoantitest-képződés is felléphet [16] (1. ábra). 


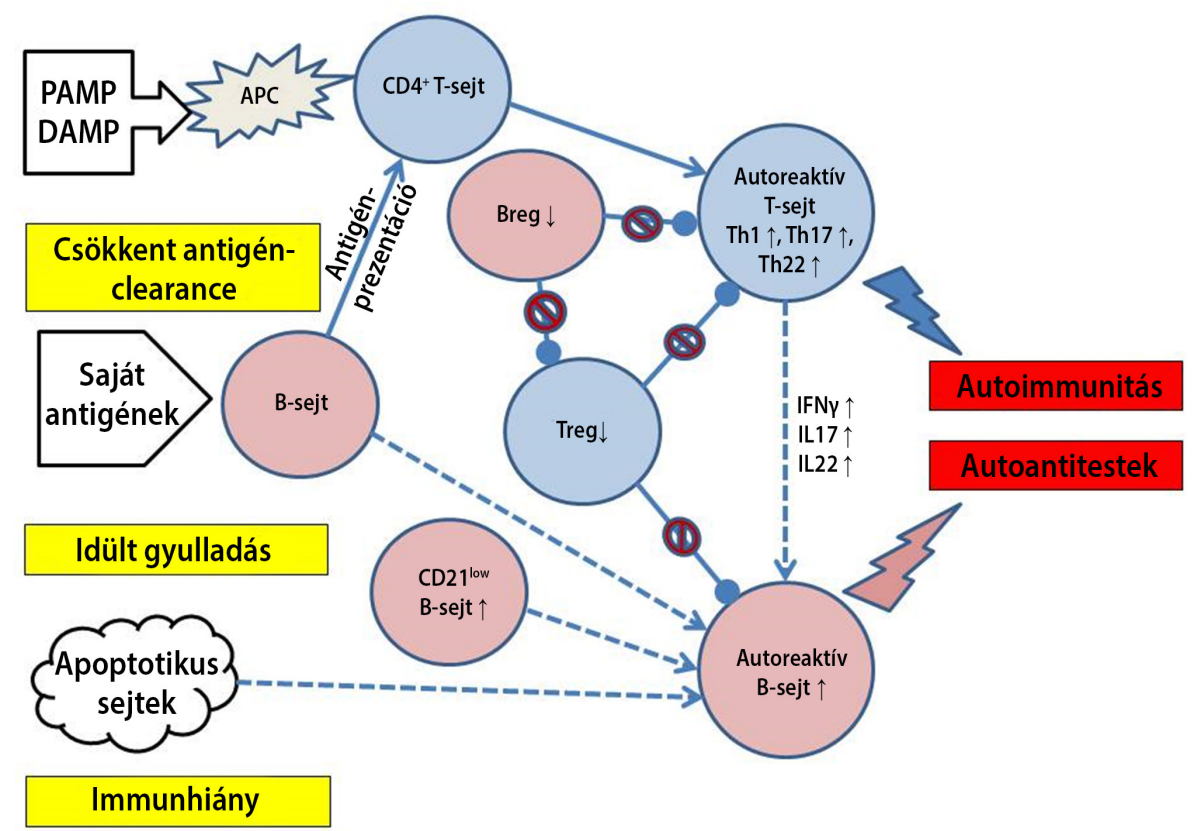

1. ábra

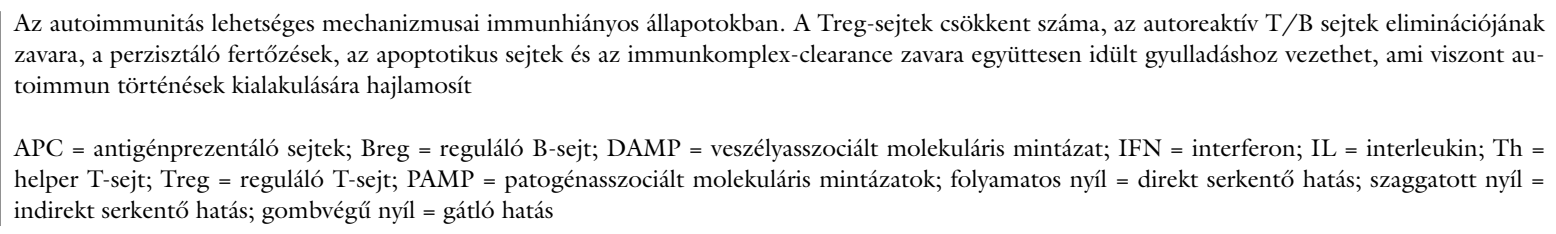

Másrészt a PID bizonyos típusaiban a gazdaszervezet hagyományos immunológiai folyamatainak alkalmatlansága a mikrobiális antigének kiküszöbölésére - alternatív, ineffektív immunválasz révén - túlzott és elhúzódó gyulladásos válaszreakciót válthat ki, ami a fertőzött és környező sejteket egyaránt károsítja [17]. Ezért primer immunhiányos betegeknél az autoimmunitás nem feltétlenül az autotolerancia elvesztését jelenti, hanem valójában azt a szövetkárosodást jelzi, amelyet a gazdaszervezet provokál az idegen antigének eltávolítására irányuló törekvése során [18] (1. ábra).

Ugyanakkor egyre inkább előtérbe kerül az a vélekedés, hogy az autoimmunitás lépései, folyamata nem egyszerűen a PID következménye, hanem valójában a PIDpatomechanizmus integráns része.

\section{Autoimmunitás az elsődleges antitesthiány (PAD) állapotaiban}

A PAD-formák altípusai: 1) minden izotípust érintő jelentősen csökkent szérum-Ig-szintek a B-sejtek számának kifejezett csökkenésével vagy hiányával. A BTK-hiány mellett ritkábban PIK3Rl-, BLNK-, $\operatorname{Ig} \alpha^{-}, \operatorname{Ig} \beta-, \lambda 5-$, $\mu$-nehézlánc-hiány vagy thymomához társuló immunhiány mutatkozhat; 2) CVID-fenotípus: legalább két Igizotípust érintő jelentősen csökkent szérumszint normális vagy csökkent B-sejtszám mellett. A CVID-en kívül számos új, monogénes defektusra visszavezethető CVID-szerú állapot sorolható ide, mint a CD19-, CD20-, CD21-, CD81-, TACI-, ICOS-, LRBA-,
PLCG2-, BAFFR-, PTEN-hiány, valamint az NFkBl/2hiány; 3) jelentősen csökkent IgG- és IgA-szintek mellett normális vagy magas IgM-szint, normális B-sejtszám. A CD40-, CD40L-, AICDA- és UNG-hiány tartozik ebbe a csoportba); 4) izotípus- vagy könnyúlánchiány, normális B-sejtszám. Az sIgAD mellett fóbb képviselői az Ig-nehézlánc mutációk/deletiók, $\kappa$-lánchiány, IgA- és IgG-alosztály-hiányok, PKC $\delta$-hiány, IgGalosztály-hiány és az aktivált PI3K $\delta$-hiány; 5 ) specifikusantitest-hiányok; és 6) újszülöttek átmeneti hypogammaglobulinaemiája normális B-sejt-számmal [9, 19].

A PAD eseteiben az autotolerancia kialakulásának defektusai mellett a tolerancia folyamatának megszakadása is autoimmun jelenségek kialakulásához vezethet. A centrális tolerancia zavara a T-sejtek vonatkozásában érintheti a klonális deletiót és a természetes szabályzó nTreg-sejtek fejlődését. A B-sejtek tekintetében is károsodhat a deletio, emellett a receptorszerkesztés (editing), illetve az ignorancia $[20,21]$. Az elégtelen perifériás tolerancia a T-sejtekben az anergia, a tolerogen antigénprezentáló sejtek és a deletio károsodása révén nyilvánulhat meg. A B-sejtek vonatkozásában is sérülhet az anergia, a deletio, a gátlóreceptorok általi szabályozás [20] (1. táblázat).

A PAD-betegekben különösen gyakoriak az autoimmun megnyilvánulások: elsősorban vérképző szervi eltérések (autoimmun cytopeniák: neutropenia, AIHA, ITP), ATD, autoimmun nephritis, illetve RA kialakulásával lehet számolni [22]. 
1. táblázat $\mid$ Az autotolerancia kisiklásának ismert mechanizmusai PAD-ban

\begin{tabular}{|c|c|c|c|}
\hline $\begin{array}{l}\text { A tolerancia } \\
\text { típusa }\end{array}$ & $\begin{array}{l}\text { Sejt- } \\
\text { típus }\end{array}$ & $\begin{array}{l}\text { Tolerancia- } \\
\text { mechanizmus }\end{array}$ & $\begin{array}{l}\text { A toleranciazavar } \\
\text { mechanizmusa }\end{array}$ \\
\hline \multirow[t]{5}{*}{ Centrális } & \multirow[t]{2}{*}{ T-sejt } & Klonális deletio & $\begin{array}{l}\text { A negatív szelekció zavarai } \\
\text { (AIRE-gén-mutáció) } \\
\text { Károsodott MHCII- } \\
\text { expresszió } \\
\text { Szekvesztrált saját antigének } \\
\text { felszabadulása } \\
\text { Saját és nem saját antigének } \\
\text { kapcsolódása }\end{array}$ \\
\hline & & $\begin{array}{l}\text { Természetes } \\
\text { szabályzó } \\
\text { T-sejtek } \\
\text { (nTreg) } \\
\text { fejlődése }\end{array}$ & $\begin{array}{l}\text { A FOXP3- és IL2-receptor- } \\
\text { gének hibái }\end{array}$ \\
\hline & \multirow[t]{3}{*}{ B-sejt } & Deletio & $\begin{array}{l}\text { Az apoptózis zavarai } \\
\text { Molekuláris mimikri }\end{array}$ \\
\hline & & $\begin{array}{l}\text { Receptorszer- } \\
\text { kesztés } \\
\text { (editing) }\end{array}$ & $\begin{array}{l}\text { Molekuláris mimikri } \\
\text { Az újrarendeződés } \\
\text { folyamatának zavarai }\end{array}$ \\
\hline & & Ignorancia & $\begin{array}{l}\text { Folyamatos gyulladás } \\
\text { Az antigének exogen } \\
\text { modifikációja }\end{array}$ \\
\hline \multirow[t]{7}{*}{ Perifériás } & \multirow[t]{3}{*}{ T-sejt } & Anergia & $\begin{array}{l}\text { CTLA4-defektus } \\
\text { Kostimuláló molekulák } \\
\text { fokozott expressziója } \\
\text { IDO-szuppresszió } \\
\text { Károsodott MHCII-ex- } \\
\text { presszió } \\
\text { Saját antigének fokozott } \\
\text { termelődése } \\
\text { Gyulladásos mediátorok } \\
\text { felszabadulása } \\
\text { Molekuláris mimikri }\end{array}$ \\
\hline & & $\begin{array}{l}\text { Tolerogen } \\
\text { antigén- } \\
\text { prezentáló } \\
\text { sejtek }\end{array}$ & $\begin{array}{l}\text { Kostimuláló molekulák } \\
\text { fokozott expressziója }\end{array}$ \\
\hline & & Deletio & $\begin{array}{l}\text { Az apoptózis-jelátvitel } \\
\text { zavarai } \\
\text { Virális apoptózisinhibitorok } \\
\text { Halálreceptorok defektusai }\end{array}$ \\
\hline & \multirow[t]{4}{*}{ B-sejt } & Anergia & $\begin{array}{l}\text { Gyulladásos környezet } \\
\text { Károsodott T-sejt-aktiváció }\end{array}$ \\
\hline & & Deletio & Fas/FasL defektus \\
\hline & & $\begin{array}{l}\text { Gátlórecepto- } \\
\text { rok általi } \\
\text { szabályozás }\end{array}$ & $\begin{array}{l}\text { Kostimuláló receptorok } \\
\text { hibás aktivációja } \\
\text { SHPl-defektus }\end{array}$ \\
\hline & & $\begin{array}{l}\text { B-sejt-szabályo- } \\
\text { zás }\end{array}$ & $\begin{array}{l}\text { Az ILl0- és a TGF } \beta \text { - } \\
\text { termelés zavarai }\end{array}$ \\
\hline
\end{tabular}

AIRE = autoimmun regulátor; CTLA4 = citotoxikus T-lypmphocytaasszociált fehérje-4; Fas $=$ CD95; FOXP3 $=$ forkhead box protein -3 IDO = indolamin-2,3-dioxigenáz; SHPl = Src-homológ-régió- 2 domént tartalmazó foszfatáz-1; TGF = transzformáló növekedési faktor

$X L$ agammaglobulinaemia (XLA). A Bruton-féle agammaglobulinaemia csak fiúkat megbetegítő, XL öröklődésư: a B-sejtek csökkent száma/hiánya és az antitestek alacsony szintje jellemzi. Az X-kromoszómán lévő BTK mutációja okozza. XLA-s betegekben ritkábban jelenik meg autoimmunitás, ugyanakkor a Treg-sejtek fejlődési zavara, az IgM típusú autoantitestek jelenléte, az autoreaktív B-sejtek deletiójának hibája, a natív immunitás okozta hibás T-sejt-aktiváció és a B-sejt-receptor editing zavara mégis hozzájárulhat autoimmun kórképek kialakulásához. Körükben gyakrabban észlelhető RA, JIA, alopecia, vitiligo, cytopeniák (neutropenia, AIHA, ITP), endocrin zavarok (T1DM, ATD-hypothyreosis), progresszív neurodegeneratio, olykor dermatomyositisszerú állapot, illetve a vasculitisek közül a Kawasaki-betegség [23].

Variábilis immunhiány (CVID). Visszatérő infekciók, hypogammaglobulinaemia jellemzi; gyakori immunhiány-állapot. Általában fiatal felnőtt korban diagnosztizálják. Pontos genetikai háttere egyelőre ismeretlen. Az autoreaktív CD2 $1^{\text {low }}$ B-sejtek proliferatiója, az Fc $\gamma$ RIIBgátló jelátvitel hiánya, a károsodott BAFF/APRIL túlélési szignál, a Treg-sejtek számának csökkenése és a hibás TCR-jelátvitel egyaránt hozzájárul autoimmun kórképek kialakulásához [24]. A CVID-es betegek közel 30\%-ában lép fel autoimmun betegség, elsősorban autoimmun cytopenia (neutropenia, ITP, AIHA) formájában. Emellett AP, ATD, TIDM, AH, PBC, vitiligo, psoriasis, interstitialis tüdőbetegség, illetve SLE, RA, SS, vasculitis, dermatomyositis és recidív polychondritis is megjelenhet. Nem ritka, hogy CVID-ben autoimmun betegség az immunhiányos állapot első, vezető klinikai megnyilvánulása [25].

Hiper-IgM szindróma (HIGM). A heterogén immunhiánycsoportba tartozó kórállapotok hátterében döntő a B-sejt-aktivációhoz nélkülözhetetlen CD40-CD40L jelátvitel genetikai zavara, együttesen az Ig-osztály-váltás defektusával. (Más eseteiben fóként az UNG és a NEMO gének anomáliáival kell számolni.) Az érintett betegekben az immunhiány többféle autoimmun betegséggel társulhat, mint ATD, TIDM, cytopeniák (neutropenia, ITP, AIHA), AH, PBC, PSC, SLE, arthritis, uveitis [21, 26].

Szelektí IgA-hiány (sIgAD). A leggyakoribb és többnyire véletlenül felfedett PID. Visszatérő légúti, gastrointestinalis vagy urogenitalis infekciók mellett sokszor autoimmun kórállapot lehet a veleszületett immunhiány bevezető vagy egyetlen klinikai manifesztációja. Allergiás diathesis is gyakrabban lép fel. Az autoimmunitás kialakulásáért többféle mechanizmus oki szerepe jön szóba, így az IgA-ellenes tolerancia hiánya (autoreaktív B-sejtek, 30\%-ban anti-IgA-, -IgG-antitestek mutathatók ki), a molekuláris mimikri, az IC-lerakódás, a perifériás tolerancia zavarai és egyes gátló jelátviteli útvonalak defektusai [13]. Számos autoimmun kórkép - gyakorta poliautoimmunitás formájában történő - előfordulása emelhető ki, mint a cytopeniák (ITP, AIHA), endocrinopathiák (ATD, T1DM), MG, PV, psoriasis, vitiligo, illetve CeD, SLE, RA, JIA, SS, vasculitis (PAN) [27].

$\mathrm{Az}$ ismertebb PAD-kórképekkel társuló autoimmun betegségeket a 2. táblázat összegzi. 
2. táblázat | PAD-kórképekhez társuló autoimmun betegségek

\begin{tabular}{|c|c|c|}
\hline PAD & $\begin{array}{l}\text { Fő molekuláris } \\
\text { eltérés }\end{array}$ & Társuló autoimmun betegségek \\
\hline XLA & BTK-mutációk & $\begin{array}{l}\text { RA, alopecia areata, ITP, } \\
\text { AIHA, autoimmun neutrope- } \\
\text { nia, Kawasaki-betegség, } \\
\text { progresszív neurodegeneratív } \\
\text { betegség }\end{array}$ \\
\hline $\begin{array}{l}\text { Good- } \\
\text { szindróma }\end{array}$ & Ismeretlen & $\begin{array}{l}\text { ITP, MG, tiszta vörösvérsejt- } \\
\text { aplasia, AP, T1DM }\end{array}$ \\
\hline CVID & Ismeretlen & $\begin{array}{l}\text { ITP, AIHA, RA, SLE, ATD, } \\
\text { AP, SS, PBC, vitiligo }\end{array}$ \\
\hline ICOS-hiány & ICOS & RA, SLE, sclerosis multiplex \\
\hline $\begin{array}{l}\text { Hiper-IgM- } \\
\text { szindróma }\end{array}$ & $\begin{array}{l}\text { CD40L- és } \\
\text { CD40-mutációk }\end{array}$ & $\begin{array}{l}\text { ATD, RA, AIHA, autoimmun } \\
\text { glomerulonephritis, uveitis, } \\
\text { SLE }\end{array}$ \\
\hline sIgAD & $\begin{array}{l}\text { Ismeretlen } \\
\text { (TACI?) }\end{array}$ & $\begin{array}{l}\text { ITP, AIHA, PV, SLE, RA, } \\
\text { JIA, SS, MG, TIDM, ATD, } \\
\text { coeliakia, psoriasis, vitiligo, } \\
\text { polyarteritis nodosa }\end{array}$ \\
\hline PKCঠ-hiány & PKC $\delta$ & $\begin{array}{l}\text { Autoimmun glomeruloneph- } \\
\text { ritis, SLE, APS, ALPS }\end{array}$ \\
\hline $\begin{array}{l}\text { Aktivált PI3K } \delta \\
\text { szindróma }\end{array}$ & $\begin{array}{l}\text { PI3KC } \delta \text { gain-of- } \\
\text { function mutációk }\end{array}$ & $\begin{array}{l}\text { RA, SLE, autoimmun } \\
\text { neutropenia, sclerosis } \\
\text { multiplex }\end{array}$ \\
\hline
\end{tabular}

AIHA = autoimmun haemolyticus anaemia; ALPS = autoimmun lymphoproliferativ szindróma; $\mathrm{AP}=$ anaemia perniciosa; $\mathrm{APS}=$ antifoszfolipidszindróma; ATD = autoimmun thyreoiditis; BTK $=$ Bruton-féle tirozinkináz; CVID = variábilis immunhiány; ICOS = indukálható kostimulátor; $\mathrm{Ig}=$ immunglobulin; ITP = immunthrombocytopenia; JIA = juvenilis idiopathiás arthritis; $\mathrm{MG}=$ myasthenia gravis; $\mathrm{PAD}=$ elsőd leges antitesthiányos állapot; $\mathrm{PBC}=$ primer biliaris cirrhosis; $\mathrm{PV}=$ pemphigus vulgaris; $\mathrm{RA}=$ rheumatoid arthritis; sIgAD = szelektív IgA hiány; SLE = szisztémás lupus erythematosus; SS = Sjögren-szindróma; T1DM = 1-es típusú diabetes mellitus; TACI = transzmembrán aktiváló és kalciummodulátor ciklofilinligand-közremúködő; XLA = $\mathrm{X}$-hez kötött agammaglobulinaemia, Bruton-féle agammaglobulinaemia

\section{Autoimmunitás a kombinált immunhiány (CID) állapotaiban}

Súlyos kombinált immunbiány (severe combined immunodeficiency, SCID). A celluláris és a humorális immunitás zavarával járó kórképek rendkívül heterogén csoportját képviseli, melyek hátterében génmutációk sokasága igazolódott. (A T- $\mathrm{B}^{+}$formákat egyebek között JAK3-, IL7R $\alpha$-, CD45-, CD3-hiány okozza.) SCID-ben hibás az autoreaktív T-sejt-klónok felszámolásáért felelős centrális tolerancia, mivel a thymusban jelentősen csökken a TSA kifejeződését szabályzó AIRE-gén expressziója. SCID-ben a perifériás tolerancia zavara is kimutatható. A jelentős lymphopenia következtében kialakult T-sejthiány, illetve a FOXP3 + Treg-sejtek számának csökkenése egyaránt lehetôvé teszi a különféle szöveteket infiltráló autoreaktív T-sejtek proliferatióját. Klinikailag a visszatérő súlyos infekciók, idült hasmenés, fejlődésbeli elmara- dás mellett autoimmun kórképek megjelenése is jellemzi. Így a SCID kedvez autoimmun endocrinopathiák (ATD, TIDM, autoimmun adrenalitis/Addison-kór), cytopeniák (ITP, AIHA), AP, autoimmun enteropathia, AH, alopecia, vitiligo, illetve RA kialakulásának $[28,29]$. Az ADA-gén mutációja, valamint a PNP-deficientia által jellemzett esetekben az autoimmun cytopeniák (neutropenia, AIHA, ITP) állnak előtérben.

Omenn-szindróma (OS). AR öröklődésú SCID, homozigóta vagy compound heterozigóta formában manifesztálódhat. Elsősorban a T/B sejtek differenciálódásához, a V(D)J-rekombinációhoz nélkülözhetetlen RAGl és RAG2 gének mutációjára vezethető vissza (T-BSCID). Emellett számos egyéb gén, mint az ADA, Artemis, IV-es típusú DNS-ligáz, ZAP70 germline hypomorph mutációi is előidézhetik. Legfőbb jellemzőjje a periférián nagyszámú oligoklonális autoreaktív T-sejt megjelenése. Visszatéró fertőzések mellett desquamativ erythrodermia, alopecia, idült hasmenés (enteritis), hepatosplenomegalia, lymphadenopathia uralja a klinikumot $[29,30]$. Az ismertebb CID-kórképekkel társuló autoimmun betegségeket a 3. táblázat összegzi.

\section{Autoimmunitás a kombinált immunhiány (CID) szindrómás állapotaiban}

Di George-szindróma (DGS). A thymus fejlődési rendellenessége miatt a T-sejtek vonatkozásában a centrális tolerancia zavara, az autoreaktív T-sejtek túlélése és a Tregsejtek fejlődési hibái is megmutatkoznak. Genetikai alapja kromoszomális microdeletio (22q11.2), ennek következtében pedig az AIRE hibás expressziója. Autoimmun kórképek a betegek közel 10\%-ában manifesztálódnak, fóként cytopeniák (ITP, AIHA), AH, vitiligo, endocrinopathiák (elsősorban ATD), illetve JIA-szerú polyarthritis formájában [30].

Wiskott-Aldrich-szindróma (WAS). Ritka kórkép, melyet az élet első hónapjában jelentkező thrombocytopenia, ekzema és rekurráló bakteriális infekciók jellemeznek. A WAS-gén mutációja súlyos következményekkel jár: elégtelen humorális és celluláris immunitás (jellemzően a TCR/BCR, illetve a Treg-sejtek zavara) mellett a natív immunfunkciók is károsodnak. A T-sejt-apoptózis rendellenességei és a kóros sejtmotilitás egyaránt kedvez autoimmun kórképek és malignus tumorok kialakulásának. Gyakori autoimmun megnyilvánulásai: cytopeniák (a thrombopenia mellett AIHA, neutropenia), AH, vitiligo, autoimmun endocrinopathiák, uveitis, illetve vasculitis (HSP), IgA-nephropathia, polyarthritis, dermatomyositis $[29,30]$.

DNS-repair-zavarok. A DNS-javítás génmutációkon alapuló rendellenességei pleiotrop hatást gyakorolnak a sejtek fejlődésére, és egyértelmúen fokozzák malignus daganatok kialakulását. A DNS-károsodás kivédésének hibái a $\mathrm{T} / \mathrm{B}$ sejtek mélyreható defektusát eredményezik (föként az antigénspecifikus receptorkészlet, az Ig-izotípus-váltás és a szomatikus hipermutációk tekintetében). 
3. táblázat |Autoimmun betegségek CID-ben és a társuló szindrómákban

\begin{tabular}{|c|c|}
\hline Kórkép & Autoimmun betegségek \\
\hline SCID & $\begin{array}{l}\text { Autoimmun endocrinopathiák } \\
\text { (ATD, TIDM, autoimmun } \\
\text { adrenalitis/Addison-kór), } \\
\text { cytopeniák (ITP, AIHA), AP, } \\
\text { autoimmun enteropathia, AH, } \\
\text { alopecia, vitiligo, RA }\end{array}$ \\
\hline $\begin{array}{l}\text { Omenn-szindróma (RAGl/2-, } \\
\text { RMRP-, ADA-, IL2RG-, } \\
\text { Artemis-, IV-es típusú DNS-li- } \\
\text { gáz-, ZAP70-, IL7R } \alpha \text {-defektus) }\end{array}$ & $\begin{array}{l}\text { Erythrodermia, alopecia, } \\
\text { hepatosplenomegalia, lymphade- } \\
\text { nopathia }\end{array}$ \\
\hline $\begin{array}{l}\text { PNP-hiány, ADA-, IV-es típusú } \\
\text { DNS ligáz-, Cernunnos-, } \\
\text { ORAIl-, STIMl-mutációk, } \\
\text { RAGl hypomorph mutáció }\end{array}$ & AIHA, ITP \\
\hline
\end{tabular}

Di George-szindróma

ITP, AIHA, polyarthritis, AH, vitiligo, autoimmun endocrinopathiák

\begin{tabular}{ll}
\hline Wiskott-Aldrich-szindróma & $\begin{array}{l}\text { AIHA, autoimmun neutropenia, } \\
\text { AH, vitiligo, autoimmun } \\
\text { endocrinopathiák, vasculitis, } \\
\text { IgA-nephropathia, polyarthritis }\end{array}$ \\
\hline Ataxia telangiectasia & ATD, psoriasis \\
\hline POLE2 & ATD, T1DM \\
\hline Porc-haj hypoplasia & $\begin{array}{l}\text { Autoimmun cytopeniák (AIHA, } \\
\text { vörösvérsejt-aplasia, ITP), JIA, } \\
\text { súlyos SCID-szerú állapot }\end{array}$ \\
\hline
\end{tabular}

$\mathrm{ADA}=$ adenozin-dezamináz; $\mathrm{AH}=$ autoimmun hepatitis; $\mathrm{AIHA}=\mathrm{au}-$ toimmun haemolyticus anaemia; $\mathrm{AP}=$ anaemia perniciosa; Artemis = DNS-keresztkötést javító fehérje-1C; ATD = autoimmun thyreoiditis; Cernunnos $=$ nemhomológvég-csatlakozó faktor-1; IL2R $=$ interleukin-2-receptor; IL17R = interleukin-17-receptor; ITP = immunthrombocytopenia; JIA = juvenilis idiopathiás arthritis; ORAIl = kalciumfelszabadulás által aktivált kalciummodulátor- $1 ; \mathrm{PNP}=$ purin-nukleozidfoszforiláz; POLE2 = DNS-polimeráz epszilon-2 alegysége; RA = rheumatoid arthritis; RAG = rekombinációaktiváló gén; RMRP $=$ a mitokondriális RNS processing endoribonukleáz RNS-alkotója; SCID = súlyos kombinált immunhiány; STIMI = stromalis interakciós molekula-1; ZAP70 = T-sejt-receptor-asszociált proteinkináz-70-zéta-lánc

A sejteket kromoszómainstabilitás és fokozott radioszenzitivitás jellemzi. Legismertebb kórformái az ataxia telangiectasia, a Nijmegen-törés-szindróma, a Bloomszindróma és a POLE2-hiány. Az ataxia telangiectasia AR öröklődésű; progresszív cerebellaris ataxia és oculocutan telangiectasiák mellett kétségtelen az immunhiány. A szuppresszor T-sejt-funkció károsodása kiemelt oki tényező a társuló autoimmun kórképek tekintetében: a leggyakrabban ATD és psoriasis, olykor ILD megjelenésével kell számolni. POLE2-biány esetén rekurráló fertőzések, szisztémás BCG-infekció, facialis dysmorphia mellett autoimmun endocrinopathia (ATD, T1DM) jelentkezhet $[21,29]$.

Immunossealis dysplasiák. Jellegzetes megnyilvánulási formája a porc-haj hypoplasia (CHH). AR öröklődésű, előidézője az RMRP-gén defektusa. Az immunhiányt a végtagok növekedési zavara (chondrodysplasia), dysostosisok, gyér szőrzet kíséri. Gyakori az autoimmun cytopenia (AIHA, vörösvérsejt-aplasia, ITP) és az arthritis (JIA). Az immunhiány spektruma a súlyos SCID-szerú állapottól az enyhébb formákig terjedhet [1].

$\mathrm{Az}$ ismertebb CID-kórképekkel társuló autoimmun betegségeket a 3. táblázat összegzi.

\section{Autoimmunitás az immunregulációs zavarral jellemzett immunhiány (DID) állapotaiban}

A DID-kórképek kialakulásának alapja az immunszabályozásban/immunválaszban és a tolerancia kialakulásában szerepet játszó gének mutációja [31]. A fenotípus vonatkozásában rendkívül jellemző az autoimmun jelenségek és gyulladásos eltérések megjelenése. A fóbb DIDcsoportok a következők: 1) Treg-sejtek genetikai defektusai; 2) lymphoproliferatio nélküli autoimmunitás; 3 ) ALPS; 4) immundiszreguláció colitisszel; 5 ) lymhoproliferativ szindrómák, 6) FHL-szindrómák, hipopigmentációval vagy a nélkül [1].

Treg-sejt-defektusok. Az XL öröklésmenetü IPEXszindróma a FOXP3-gén LOF-mutációja révén a thymuseredetû szuppresszor hatású $\mathrm{CD}^{4+} \mathrm{CD}^{25+}$ Tregsejtek hiányát eredményezi. (A FOXP3 fóbb élettani hatásai között említhető még az NFAT/NFkB, s ezáltal az IL2 gátlása, illetve hogy számos egyéb gén - például CD25, CTLA4 - transzkripciós aktivátora.) A mutáció következtében - főleg a Treg-funkció kiesése révén kontrollálatlan T-sejt-proliferatio valósul meg. Kora életkortól hasmenés, ekzema, allergiás kórképek, visszatérő fertőzések és autoimmun megbetegedések jellemzik. Az autoimmunitás elsősorban enteropathia, polyendocrinopathia (T1DM, ATD), cytopeniák (neutropenia, AIHA, ITP), alopecia, vitiligo és GN (membranosus nephropathia) formájában nyilvánul meg [11, 32]. Az IPEX-szerü szindrómák hátterében fóként az IL2R $\alpha$, CTLA4, STAT3, LRBA gének mutációi állnak $[11,31]$. A CD25biány a CD25 (IL2R $\alpha$ )-gén mutációja okozta ritka kórkép, melyet számos autoimmun kórkép, így enteropathia, TIDM, ATD, bullosus pemphigoid, alopecia és ekzema megjelenése jellemez. CTLA4-hiány: az antigén stimulációja normálisan a Treg-sejtek múködését segíti elő. A kódoló gén mutációja többszörös autoimmun megbetegedések, így enteritis, cytopeniák (AIHA, ITP), ATD, psoriasis, arthritis kialakulását okozza. Az LRBAhiány a közelmúltban felfedett PID. A gén mutációja 
rekurráló infekciók mellett számos autoimmun kórkép, jellemzően cytopeniák (AIHA, ITP, neutropenia) és enteritis megjelenésére vezet, de TIDM, AH, alopecia, ekzema, uveitis is kísérheti. Kórtani alapja a Treg-sejtek fenotípusára gyakorolt hatás mellett azok apoptózisának elösegítése [32].

Lymphoproliferatio nélküli autoimmunitás. $\mathrm{Az}$ APECED (APSl) ritka, AR öröklésmenetű; az AIREgén LOF-mutációi okozzák. A gén által kódolt fehérje feladata a centrális immuntolerancia, az autoreaktív T-sejtek klonális deletiójának biztosítása. A klinikai tünetek kialakulásáért a negatív szelekció elmaradása mellett Treg-sejt-zavar is okolható. Legfóbb jellegzetességei az autoimmun polyendocrinopathia (hypoparathyreosis, Addison-kór, ATD, T1DM, hypogonadismus) és a CMC, míg az úgynevezett minor tünetek között az ectodermalis dystrophia (fóleg fogzománc-hypoplasia vagy körömdystrophia formájában) említhető. Számos egyéb autoimmun kórkép, így AIHA, neutropenia, AP, vitiligo, alopecia, enteropathia, AH, PBC, SS, esetenként ILD megjelenésével is számolni kell $[10,11,32]$. A betegekben különféle neutralizáló autoantitestek (például antiIFN $\alpha /$ IL17A/IL22) mutathatók ki, melyek részben a CMC-ért is felelőssé tehetők. Az ITCH-biány következtében az érintettekben szintén számos autoimmun betegség, így ILD, endocrin zavarok (T1DM, ATD), AH, enteropathia manifesztálódhat. Az immunreguláció zavarát az autoreaktív effektor T-sejtek és a Treg-sejtek következményes rendellenességei idézik elő.

Autoimmun lymphoproliferativ szindróma (ALPS). $\mathrm{AD}$ öröklődésű; legfontosabb kóroki tényezője az autoreaktív lymphocyták Fas (CD95)-dependens apoptózisának zavara, mely többnyire a Fas (TNFRSF6)-gén mutációjára vezethető vissza, ám ritkán egyéb géneltérések (például FasL, CASP8/10) is kiválthatják. Röviddel a születést követően jelentékeny lymphoproliferatio mutatkozik, ami hepatosplenomegaliát, lymphadenopathiát, fokozott lymphomakockázatot és számos autoimmun betegség kialakulását okozza. A leggyakoribb autoimmun kórformák cytopeniák (AIHA, ITP, neutropenia, Evans-szindróma), AP, SLE, GN (membranosus nephropathia), Guillan-Barré-szindróma, RA, vasculitis, uveitis, opticus neuritis formájában jelentkezhetnek. EBVinfekció esetén különösen megnő a lymphomakockázat [11].

Lymphoproliferativ szindrómák. Az XL öröklődésü formák (XLP1, XLP2) többnyire (fulmináns) EBV-infekció talaján manifesztálódnak, melynek immunológiai háttere a T-, NK- és NKT-sejteket érintően az intracelluláris SAP-reguláló SH2DlA gén mutációja. A SAP a centrális és perifériás tolerancia kialakításában is részt vesz. Az EBV-fertőzést gyakran májelégtelenség és haemophagocytosis kíséri. (Az igen ritka XLP2-forma hátterében az apoptózisinhibitor XIAP-gén mutációja áll.) Malignus lymphoproliferativ megbetegedés az érintettek kb. 25-40\%-ában igazolható. A betegségcsoportra autoimmun megnyilvánulások - mint vörösvérsejt-aplasia, aplasticus anaemia, ITP, AIHA, ATD, vasculitis - is jellegzetesek [11, 31]. E csoportba sorolt további kórkép az AR öröklődésû $P K C \delta$-biány; a molekula jelentős szereppel bír a sejttúlélés, proliferatio és apoptózis szabályozásában. A deficiens betegekben jellemzően kialakulhatnak autoimmun kórképek, fóleg SLE-szerü formában, GN-nel, APS-sel kísérten, valamint recidív polychondritis.

Familiaris haemophagocytosissal kisért lymphohistiocytosis (FHL)-szindrómák. Igen ritka, AR öröklésmenetü, súlyos lefolyású kórképek, melyekre kontrollálatlan Tsejt- és makrofágaktiváció, következményes, extrém emelkedett szérum-Thl-citokin-szintek, a szövetekben pedig az aktivált $\mathrm{T} / \mathrm{NK}$ sejtekből és makrofágokból álló infiltáció jellemző. Jellegzetes klinikai megnyilvánulás a láz, a jelentős hepatosplenomegalia és az autoimmun cytopeniák. Az FHL-családba hipopigmentációval kísért (Chédiak-Higashi-, Griscelli-, Hermansky-Pudlak-szindrómák) és a nélküli kórképek tartoznak; az utóbbiak közül a legismertebb a PRFl-gén mutációja miatti perforindeficientia (FHL2), az NK- és CTL-sejtek hiányzó degranulációjával [33]. Az immunreguláció kisiklása, az autotolerancia zavara okán az egyes szindrómákban a kórlefolyás során számos autoimmun betegség manifesztálódhat, a leggyakrabban SLE, JIA, illetve felnőttkori Still-féle betegség, de esetenként vasculitis (PAN), szisztémás sclerosis, dermatomyositis, SS, az idegrendszert érintően pedig CIDP is felléphet [34].

$\mathrm{Az}$ ismertebb DID-kórképekkel társuló autoimmun betegségeket a 4. táblázat összegzi.

\section{Autoimmunitás a phagocytosis (CDP) és a veleszületett immunitás (DII) zavaraiban és a komplementhiány (CD) állapotaiban}

Krónikus granulomatosus betegség (CGD). A CDP-csoportba, azon belül a 'respiratory burst' rendellenességei közé sorolt heterogén kórállapot; XL (75\%) és AR öröklődésű formái ismertek. Kórtani alapja a NADPH-oxidáz-komplex károsodása, ami az intracelluláris killing súlyos zavarát okozza. Az elektrontranszport-fehérjét kódoló CYBB-gén mutációjára vezethető vissza. Jellemzően már kisdedkorban megnyilvánul, fóként granulomás, sokszervi tályogképződés formájában. A kóros neutrophil granulocyta apoptózis és clearance, és a megfelelő szabad gyökök hiányában a Treg-sejtek hibás aktivációja egyaránt autoimmun kórképek, elsősorban SLE, SLE-szerü megbetegedések kialakulását segítik elő, de arthritis, ITP, AH is jelentkezhet [10].

STATI-hiány: a DII-csoportba tartozó PID, a gén GOF-mutációja váltja ki; legfőbb kórtani következménye a Th17-sejtek kialakulásának blokkolása. A jellemző CMC és a visszatérő infekciók mellett autoimmun betegségek, mint endocrinopathiák (ATD, TIDM), enteropathia, cytopeniák, ekzema is kísérik [21]. 
4. táblázat $\mid$ Az immunregulációs zavarral jellemzett immunhiány állapotaihoz (DID) társuló autoimmun kórképek

\begin{tabular}{|c|c|c|c|}
\hline DID-csoport & Betegség & Genetikai hiba & Társuló autoimmun betegség \\
\hline \multirow[t]{4}{*}{$\begin{array}{l}\text { A Treg-sejtek genetikai } \\
\text { defektusai }\end{array}$} & IPEX & FOXP3 & $\begin{array}{l}\text { Autoimmun enteropathia, autoimmun nephritis, } \\
\text { ATD, TIDM, ITP, AIHA, autoimmun } \\
\text { neutropenia }\end{array}$ \\
\hline & CD25-hiány & $\mathrm{CD} 25$ & $\begin{array}{l}\text { Autoimmun enteropathia, T1DM, bullosus } \\
\text { pemphigoid, ATD, alopecia }\end{array}$ \\
\hline & CTLA4-hiány & CTLA4 & $\begin{array}{l}\text { Enteritis, cytopeniák (AIHA, ITP), ATD, } \\
\text { psoriasis, arthritis }\end{array}$ \\
\hline & LRBA-hiány & LRBA & $\begin{array}{l}\text { ITP, AIHA, autoimmun neutropenia, RA, } \\
\text { granulomatosus-lymphocytás interstitialis } \\
\text { tüdőbetegség, AH, ekzema, uveitis, alopecia }\end{array}$ \\
\hline \multirow[t]{2}{*}{$\begin{array}{l}\text { Lymphoproliferatio nélküli } \\
\text { autoimmunitás }\end{array}$} & APECED & AIRE & $\begin{array}{l}\text { ATD, Addison-kór, AIHA, AP, T1DM, PBC, } \\
\text { vitiligo, alopecia }\end{array}$ \\
\hline & ITCH-hiány & ITCH & T1DM, ATD, AP, autoimmun enteropathia \\
\hline $\begin{array}{l}\text { Autoimmun lymphoproliferativ } \\
\text { szindrómák }\end{array}$ & $\begin{array}{l}\text { Fas-, FasL-, caspase-10-, } \\
\text { caspase-8-, FADD-hiány, } \\
\text { CARD11 gain-of-function } \\
\text { mutációk, } \\
\text { PKC } \delta \text {-hiány }\end{array}$ & $\begin{array}{l}\text { TNFRSF6, TNFSF6, } \\
\text { CASP10, CASP8, } \\
\text { FADD, CARD11, } \\
\text { PKC } \delta\end{array}$ & $\begin{array}{l}\text { AIHA, ITP, autoimmun neutropenia, AP, SLE, } \\
\text { Guillan-Barré-szindróma, glomerulonephritis, } \\
\text { uveitis, RA }\end{array}$ \\
\hline \multirow[t]{4}{*}{ Lymphoproliferativ szindrómák } & SH2D1A-hiány (XLPl) & SH2DlA & $\begin{array}{l}\text { Vörösvérsejt-aplasia, aplasticus anaemia, } \\
\text { vasculitis }\end{array}$ \\
\hline & XIAP-hiány (XLP2) & $\mathrm{XIAP} / \mathrm{BIRC} 4$ & ITP, AIHA \\
\hline & PKCঠ-hiány & $\mathrm{PKC} \delta$ & $\begin{array}{l}\text { SLE-szerű forma, glomerulonephritis, APS, } \\
\text { recidív polychondritis }\end{array}$ \\
\hline & CD27-hiány & $\mathrm{CD} 27$ & Haemophagocytosis \\
\hline \multirow{2}{*}{$\begin{array}{l}\text { Familiaris haemophagocytosissal } \\
\text { járó lymphohistiocytosisszindró- } \\
\text { mák }\end{array}$} & $\begin{array}{l}\text { FHL-szindrómák hipopigmen- } \\
\text { táció nélkül (FHL2,-3,-4,-5) }\end{array}$ & $\begin{array}{l}\text { PRF1, UNC13D, } \\
\text { STX11, STXBP2 }\end{array}$ & RA, SLE, dermatomyositis, SS, PAN, CIDP, AP \\
\hline & $\begin{array}{l}\text { FHL-szindrómák hipopigmen- } \\
\text { tációval (Chédiak-Higashi- } \\
\text { szindróma, 2-es típusú } \\
\text { Griscelli-szindróma, 2-es típusú } \\
\text { Hermansky-Pudlak-szindróma) }\end{array}$ & $\begin{array}{l}\text { MYO5A, RAB27A, } \\
\text { MLPH, LYST, AP3B1 }\end{array}$ & Neutropenia \\
\hline
\end{tabular}

$\mathrm{AH}=$ autoimmun hepatitis; $\mathrm{AIHA}=$ autoimmun haemolyticus anaemia; $\mathrm{AIRE}=$ autoimmun regulátor; $\mathrm{AP}=$ anaemia perniciosa; $\mathrm{AP} 3 \mathrm{~B} 1=\mathrm{adap}-$ terrel kapcsolatos fehérjekomplex-3-béta-1; APECED = autoimmun polyendocrinopathia, candidiasis, ectodermalis dystrophia; APS = antifoszfolipidszindróma; ATD = autoimmun thyreoiditis; CARD = kaszpáztoborzó alegységcsalád; CASP = kaszpáz; CIDP = krónikus gyulladásos demyelinisatiós polyneuropathia; CTLA4 = citotoxikus T-lymphocyta-asszociált fehérje-4; FADD = Fas-asszociált-halál-domén; Fas = CD95; FOXP3 = forkhead box protein-3; FHL = familiaris haemophagocytosissal járó szindrómák; IPEX = X-hez kötött immundiszreguláció, polyendocrinopathia, enteropathia; ITCH = Itchy E3-ubikvitin-fehérje-ligáz; ITP = immunthrombocytopenia; LRBA = LPS-reszponzív beige-szerű horgonyzó; LYST = lysosomalis közlekedési szabályozó; $\mathrm{MLPH}=$ melanofilin; MYO5A = myosin-VA; PAN = polyarteritis nodosa; PBC = primer biliaris cirrhosis; $\mathrm{PKC} \delta$ = fehérjekináz-C- $\delta$;RF1 = perforin-1; RA = rheumatoid arthritis; RAB27A = a RAS onkogén család tagja; SH2D1A = SH2-domén-tartalmazó-1A; SLE = szisztémás lupus erythematosus; SS = Sjögren-szindróma; STX11 = szintaxin-11; STXBP2 = szintaxinkötő fehérje-2; T1DM = 1-es típusú diabetes mellitus; TNFRSF = tumornekrózisfaktor-szupercsalád; UNC13D = Unc-13-homológ-D; XIAP = X-hez kötött apoptózisgátló fehérje; XLP = X-kromoszómához kapcsolódó lymphoproliferatio

Komplementhiány állapotaiban (CD) az ismétlődó bakteriális infekciók mellett a legklasszikusabb klinikai eltérés az SLE és olykor HAE együttes előfordulása. A komplementkaszkád korai elemeinek $(\mathrm{Clq}, \mathrm{Clr}, \mathrm{Cls}$, C2, C4) genetikai hátterú múködési zavara egyértelmúen szisztémás autoimmun betegségre, döntően SLE-re hajlamosít, olykor DLE formájában; szervspecifikus autoimmun kórképek viszont nem alakulnak ki. Gyakori a GN. A korai komponenshiány eseteiben sérül az IC-ek, apoptotizáló sejtek opsonisatiója, eliminációja, ami részben a fokozott IFN $\alpha$-expresszió révén - a T/B-sejttolerancia áttöréséhez vezet $[10,15]$.

\section{Megbeszélés}

Az elméleti immunológia és a molekuláris biológia nagyívű fejlődése, a számtalan új módszer bevezetése tette lehetôvé, hogy változzanak az immunrendszert érintő egyes betegségcsoportok - autoimmun, allergiás, immunhiányos állapotok - patogenezisérôl kialakított hagyományos nézeteink [32].

A rendkívül heterogén veleszületett/primer immunhiányos kórképek a természetes és az adaptív immunrendszer kompetens sejtjeinek genetikai - fóként monogénes természetú - rendellenességeire vezethetôk vissza. 
Az immunhiány és az autoimmunitás az immunregulációs zavar (látszólag) eltérő, ellentétes kimenetelét képviselő kórformák. Ugyanakkor PID-ben az autoimmun jelenségek, a legkülönfélébb (szerv/sejt specifikus és szisztémás) autoimmun kórképek - az egészséges populációhoz viszonyított átlagosan 10-25× - gyakoribb előfordulása, valamint az autoimmun betegek körében esetenként - akár 15\%-ban - megfigyelhető primer immunhiány az immunszabályozás inherens, komplex és feltétlenül átfedő zavarát valószínúsíti [3, 15]. Egyre nyilvánvalóbb az a vélekedés, mely szerint az autoimmunitás nem egyszerüen a PID következménye, hanem valójában a PID-patomechanizmus integráns része [32, 35].

PID-ben az igen változatos fenotípusok közös, jellemző tünete, a visszatérő infekciók mellett a klinikai képet elsősorban autoimmun természetű megnyilvánulások uralják. Esetenként az autoimmun jelenség/kórkép számos PID bevezető, olykor egyetlen(!) tünete lehet, és fertőzések csak a progresszió során jelentkeznek. Főként a T-sejteket (is) érintő típusokban kifejezett az autoimmun betegség/ek kialakulási rizikója [32]. A leggyakoribb sejt/szerv specifikus kórformákat az autoimmun cytopeniák, az endocrin szervek rendellenségei és az autoimmun enteropathia, míg a szisztémás betegségek tekintetében az SLE és az arthritisek képviselik. Poliautoimmunitás kialakulása sem ritka.

Életkilátások tekintetében a PID-del társuló autoimmunitás egyértelmúen előnytelen prognosztikai faktort képvisel [5]. PID-ben az autoimmun betegségek időben történő felismerése némely esetben komoly kihívást jelent, hiszen például a hypogammaglobulinaemia és a celluláris immunhiány egyaránt lényegesen befolyásolhatja az immunszerológiai és hisztológiai eredményeket. Másrészt a dominálóan autoimmun kórkép formájában induló fenotípusoknál késedelmet szenvedhet az egyidejü PID kórismézése.

A jövő kutatásai hivatottak tovább bővíteni, pontosítani a primer immunhiány és az autoimmunitás közötti komplex immunbiológiai összefüggéseket, megalapozva az indokolt kezelés elméleti hátterét.

\section{Esetismertetés}

\section{Klinikai leírás}

A 45 éves férfi immunológiai konzíliumát kardiológus kollégák kezdeményezték hónapok óta tapasztalt NYHA III. stádiumú szívelégtelenség, echockardiográfiával igazolt súlyos fokú, ismeretlen etiológiájú DCM alapján. (EF: 19\%; EKG: bal-Tawara-szár-blokk, multifokális kamrai Es-ek; koronarográfia: ép erek; kardio-MRI: tág bal kamra, diffúz hypokinesis.) Anamnézisében lényegi előző megbetegedés nem szerepelt. A szívelégtelenség jellemző tünetei mellett új keletü, diffúz, kis- és nagyízületi fájdalmakra is panaszkodott.

\section{Kivizsgálás}

Rutin laboratóriumi leleteiben érdemi kórjelző eltérés nem mutatkozott. Esetében (totális) sIgAD-t igazoltunk (ESID-kritériumok: szérum $\mathrm{IgG} / \mathrm{M}$, perifériás B-sejtszubpopuláció-, illetve $\mathrm{CD}^{4+}, \mathrm{CD}^{8+}$ T-sejt-megoszlás: normális). Az sIgAD gyakran (5-30\%) társul autoimmun jelenségekkel, ezért a DCM és az arthralgia hátterében is autoimmun megbetegedés(ek)re gyanakodtunk. Valóban, a betegnél CeD és RA egyidejü fennállását bizonyítottuk. (Anti-tTG/IgG: 25145 U; gasztroszkópia: elsimult, csipkézett szélü Kerckring-redők, mozaikszerü mucosarajzolat; hisztológia: Marsh III/c boholyatrophia, egyértelmű CeD, illetve ACPA: 1275 U.) Ezek alapján az sIgAD úgynevezett autoimmun fenotípusát véleményeztük [36].

\section{Kezelés}

Élethosszig indokolt gluténmentes diéta mellett metotrexát-bázisterápiát vezettünk be. Hónapok múlva a domináló szívelégtelenség tünetei szignifikánsan mérséklődtek, és a beteg ízületi fájdalmai is lényegesen enyhültek. (Kontroll-echokardiográfián javulás: az EF 39, majd 58\%-ra módosult, míg immunszerológia során az anti-tTG csökkent [3927-1211 U], hasonlóképpen az ACPA is [922-338 U].)

\section{Következtetés}

Az sIgAD-asszociált szisztémás autoimmun kórképek tekintetében az RA és a CeD egyaránt előtérben áll [37], és olykor a PID domináló klinikai megnyilvánulása(i) lehet(nek) (úgynevezett noninfektív, autoimmun fenotípus). DCM-es betegek között a CeD előfordulása egyértelműen gyakoribb, és fordítva, CeD-ben szenvedőknél fokozott az idiopathiás DCM kialakulásának valószínüsége [38]. RA és CeD társulásának alapjául elsősorban az úgynevezett bél-ízület tengely szolgálhat, melynek értelmében az RA patomechanizmusában az autoimmun synovitis végső soron bélnyálkahártya-eredetű neoantigén epitópok által indukált gyulladásos történésekre vezethető vissza [39]. Bár RA-ban a cardiovascularis érintettség kifejezett, DCM kialakulása mégsem jellemzi.

Anyagi támogatás: A kézirat megírása, illetve a kapcsolódó kutatómunka anyagi támogatásban nem részesült.

Szerzői munkamegosztás: M. Gy.: A cikk szerzője, a szakirodalom kutatása, feldolgozása, a kézirat tartalmának szerkesztője, kritikus lektorálója. S. F.: Társszerző, a szakirodalom kutatása, feldolgozása, a táblázatok és ábra szerkesztője. A cikk végleges változatát mindkét szerző elolvasta és jóváhagyta.

Érdekeltségek: A szerzőknek nincsenek érdekeltségeik. 


\section{Irodalom}

[1] Picard C, Bobby Gaspar H, Al-Herz W, et al. International Union of Immunological Societies: 2017 Primary Immunodeficiency Diseases Committee report on inborn errors of immunity. J Clin Immunol. 2018; 38: 96-128.

[2] Bousfiha AA, Jeddane L, Ailal F, et al. Primary immunodeficiency diseases worldwide: more common than generally thought. J Clin Immunol. 2013; 33: 1-7.

[3] Fischer A, Provot J, Jais JP, et al. Autoimmune and inflammatory manifestations occur frequently in patients with primary immunodeficiencies. J Allergy Clin Immunol. 2017; 140: 1388-1393. e8.

[4] Saifi M, Wysocki CA. Autoimmune disease in primary immunodeficiency: at the crossroads of anti-infective immunity and selftolerance. Immunol Allergy Clin North Am. 2015; 35: 731-752.

[5] Azizi G, Ziaee V, Tavakol M, et al. Approach to the management of autoimmunity in primary immunodeficiency. Scand J Immunol. 2017; 85: 13-29.

[6] Farmand S, Baumann U, von Bernuth H, et al. Interdisciplinary AWMF guideline for the diagnostics of primary immunodeficiency. Klin Padiatr. 2011; 223: 378-385.

[7] Picard C, Al-Herz W, Bousfiha A, et al. Primary immunodeficiency diseases: an update on the classification from the International Union of Immunological Societies Expert Committee for Primary Immunodeficiency 2015. J Clin Immunol. 2015; 35 696-726.

[8] Bousfiha A, Jeddane L, Picard C, et al. The 2017 IUIS phenotypic classification for primary immunodeficiencies. J Clin Immunol. 2018; 38: 129-143.

[9] Azizi G, Ahmadi M, Abolhassani H, et al. Autoimmunity in primary antibody deficiencies. Int Arch Allergy Immunol. 2016; 171: 180-193.

[10] Dimitriades VR, Sorensen R. Rheumatologic manifestations of primary immunodeficiency diseases. Clin Rheumatol. 2016; 35: 843-850.

[11] Azizi G, Pouyani MR, Abolhassani H, et al. Cellular and molecular mechanisms of immune dysregulation and autoimmunity. Cell Immunol. 2016; 310: 14-26.

[12] Wong T, Yeung J, Hildebrand KJ, et al. Human primary immunodeficiencies causing defects in innate immunity. Curr Opin Allergy Clin Immunol. 2013; 13: 607-613

[13] Arason GJ, Jorgensen GH, Ludviksson BR. Primary immunodeficiency and autoimmunity: lessons from human diseases. Scand J Immunol. 2010; 71: 317-328.

[14] Atkinson TP. Immune deficiency and autoimmunity. Curr Opin Rheumatol. 2012; 24: 515-521.

[15] Grimbacher B, Warnatz K, Yong PFK, et al. The crossroads of autoimmunity and immunodeficiency: Lessons from polygenic traits and monogenic defects. J Allergy Clin Immunol. 2016; 137: 3-17.

[16] Westerberg LS, Klein C, Snapper SB. Breakdown of T cell tolerance and autoimmunity in primary immunodeficiency - lessons learned from monogenic disorders in mice and men. Curr Opin Immunol. 2008; 20: 646-654

[17] Pillai S. Rethinking mechanisms of autoimmune pathogenesis. J Autoimmun. 2013; 45: 97-103.

[18] Arkwright PD, Abinun M, Cant AJ. Autoimmunity in human primary immunodeficiency diseases. Blood 2002; 99: 2694 2702.

[19] Durandy A, Kracker S, Fischer A. Primary antibody deficiencies. Nat Rev Immunol. 2013; 13: 519-533.

[20] Coutinho A, Carneiro-Sampaio M. Primary immunodeficiencies unravel critical aspects of the pathophysiology of autoimmunity and of the genetics of autoimmune disease. J Clin Immunol. 2008; 28(Suppl 1): S4-S10.

[21] Giardino G, Gallo V, Prencipe R, et al. Unbalanced immune system: immunodeficiencies and autoimmunity. Front Pediatr. 2016; 4: 107

[22] Azizi G, Tavakol M, Rafiemanesh H, et al. Autoimmunity in a cohort of 471 patients with primary antibody deficiencies. Expert Rev Clin Immunol. 2017; 13: 1099-1106.

[23] Hernandez-Trujillo VP, Scalchunes C, Cunningham-Rundles C, et al. Autoimmunity and inflammation in X-linked agammaglobulinemia. J Clin Immunol. 2014; 34: 627-632.

[24] Azizi G, Abolhassani H, Asgardoon MH, et al. Autoimmunity in common variable immunodeficiency: epidemiology, pathophysiology and management. Expert Rev Clin Immunol. 2017; 13: $101-115$.

[25] Xiao X, Miao Q, Chang C, et al. Common variable immunodeficiency and autoimmunity - an inconvenient truth. Autoimmun Rev. 2014; 13: 858-864.

[26] Lehman HK. Autoimmunity and immune dysregulation in primary immune deficiency disorders. Curr Allergy Asthma Rep. $2015 ; 15: 53$.

[27] Abolhassani H, Gharib B, Shahinpour S, et al. Autoimmunity in patients with selective IgA deficiency. J Investig Allergol Clin Immunol. 2015; 25: 112-119.

[28] Milner JD, Fasth A, Etzioni A. Autoimmunity in severe combined immunodeficiency (SCID): lessons from patients and experimental models. J Clin Immunol. 2008; 28(Suppl 1): S29S33.

[29] Azizi G, Ghanavatinejad A, Abolhassani H, et al. Autoimmunity in primary T-cell immunodeficiencies. Expert Rev Clin Immunol. 2016; 12: 989-1006.

[30] Cirillo E, Giardino G, Gallo V, et al. Severe combined immunodeficiency - an update. Ann N Y Acad Sci. 2015; 1356: 90-106

[31] Kuchroo VK, Ohashi PS, Sartor RB, et al. Dysregulation of immune homeostasis in autoimmune diseases. Nat Med. 2012; 18: $42-47$.

[32] Maródi L. Inborn errors of T cell immunity underlying autoimmune diseases. Expert Rev Clin Immunol. 2017; 13: 97-99.

[33] Pállinger E, Erdélyi D, Kovács G, et al. Flow cytometry in the diagnosis of hemophagocytic lymphohistiocytosis. [Az áramlási citometria jelentősége a haemophagocytás lymphohistiocytosis diagnosztikájában egy fatális kimenetelû eset bemutatása kapcsán.] Orv Hetil. 2014; 155: 389-395. [Hungarian]

[34] Gholam C, Grigoriadou S, Gilmour KC, et al. Familial haemophagocytic lymphohistiocytosis: advances in the genetic basis, diagnosis and management. Clin Exp Immunol. 2011; 163: $271-283$

[35] Maródi L. Modern view of primary immunodeficiencies. [A primer immundeficienciák modern szemlélete.] Orvostovábbképző Szle. 2017; 24: 36-43. [Hungarian]

[36] Yazdani R, Latif A, Tabassomi F, et al. Clinical phenotype classification for selective immunoglobulin A deficiency. Expert Rev Clin Immunol. 2015; 11: 1245-1254.

[37] Wang N, Shen N, Vyse TJ, et al. Selective IgA deficiency in autoimmune diseases. Mol Med. 2011; 17: 1383-1396.

[38] Emilsson L, Andersson B, Elfström P, et al. Risk of idiopathic dilated cardiomyopathy in 29000 patients with celiac disease. J Am Heart Assoc. 2012; 1: e001594.

[39] Lerner A, Matthias T. Rheumatoid arthritis-celiac disease relationship: joints get that gut feeling. Autoimmun Rev. 2015; 14 : 1038-1047.

(Múzes Györgyi dr., Budapest, Szentkirályi u. 46., 1088 e-mail: muzes.gyorgyi@med.semmelweis-univ.hu) feltéve, hogy az eredeti szerző és a közlés helye, illetve a CC License linkje és az esetlegesen végrehajtott módositások feltüntetésre kerülnek. 